\title{
Functional trait responses to sediment deposition reduce macrofauna-mediated ecosystem functioning in an estuarine mudflat
}

\author{
Sebastiaan Mestdagh $^{1}$, Leila Bagaço ${ }^{1}$, Ulrike Braeckman ${ }^{1}$, Tom Ysebaert ${ }^{2,3},{\text { Bart De } \text { Smet }^{1, \text { a }} \text {, Tom Moens }}^{1}$, and \\ Carl Van Colen ${ }^{1}$ \\ ${ }^{1}$ Ghent University, Marine Biology Research Group, Krijgslaan 281/S8, 9000 Ghent, Belgium \\ ${ }^{2}$ Department of Estuarine and Delta Systems, NIOZ Royal Netherlands Institute for Sea Research and Utrecht University, \\ P.O. Box 140, 4400 AC Yerseke, the Netherlands \\ ${ }^{3}$ Wageningen University and Research, Wageningen Marine Research, P.O. Box 77, 4400 AB Yerseke, the Netherlands \\ ${ }^{a}$ present address: Flanders Marine Institute, Wandelaarkaai 7, 8400 Oostende, Belgium
}

Correspondence: Sebastiaan Mestdagh (sebastiaan.mestdagh@ugent.be)

Received: 10 October 2017 - Discussion started: 25 October 2017

Revised: 3 April 2018 - Accepted: 21 April 2018 - Published: 4 May 2018

\begin{abstract}
Human activities, among which dredging and land use change in river basins, are altering estuarine ecosystems. These activities may result in changes in sedimentary processes, affecting biodiversity of sediment macrofauna. As macrofauna controls sediment chemistry and fluxes of energy and matter between water column and sediment, changes in the structure of macrobenthic communities could affect the functioning of an entire ecosystem. We assessed the impact of sediment deposition on intertidal macrobenthic communities and on rates of an important ecosystem function, i.e. sediment community oxygen consumption (SCOC). An experiment was performed with undisturbed sediment samples from the Scheldt river estuary (SW Netherlands). The samples were subjected to four sedimentation regimes: one control and three with a deposited sediment layer of 1,2 or $5 \mathrm{~cm}$. Oxygen consumption was measured during incubation at ambient temperature. Luminophores applied at the surface, and a seawater-bromide mixture, served as tracers for bioturbation and bio-irrigation, respectively. After incubation, the macrofauna was extracted, identified, and counted and then classified into functional groups based on motility and sediment reworking capacity. Total macrofaunal densities dropped already under the thinnest deposits. The most affected fauna were surficial and low-motility animals, occurring at high densities in the control. Their mortality resulted in a drop in SCOC, which decreased steadily with increasing deposit thickness, while bio-irrigation and bioturbation activity showed increases in the lower sediment deposition
\end{abstract}

regimes but decreases in the more extreme treatments. The initial increased activity likely counteracted the effects of the drop in low-motility, surficial fauna densities, resulting in a steady rather than sudden fall in oxygen consumption. We conclude that the functional identity in terms of motility and sediment reworking can be crucial in our understanding of the regulation of ecosystem functioning and the impact of habitat alterations such as sediment deposition.

\section{Introduction}

It is widely accepted that biodiversity plays an important role in ecosystem functioning. A higher biodiversity can convey a higher resilience and a more efficient functioning of ecosystems in terms of, for example, nutrient cycling and primary productivity (Cardinale et al., 2012; Hooper et al., 2005). Since biodiversity-mediated ecosystem functioning depends on the functional identities of the species present in the community and their densities (Braeckman et al., 2010; Van Colen et al., 2013), functional community descriptors often predict functioning better than taxonomic diversity (Wong and Dowd, 2015). Functional traits, e.g. in terms of motility or sediment reworking rate, can be an indication for a species' behaviour. By being able to rework more or less sediment, species can differentially influence biogeochemical cycling (Wrede et al., 2017). Furthermore, variations in population densities of individual species can 
influence the ecosystem functioning as well (e.g. Braeckman et al., 2010). Habitat changes that alter densities and/or induce behavioural change of specific functional groups of organisms, e.g. top predators or key players in biogeochemical cycling (Allen and Clarke, 2007; Villnäs et al., 2012), are therefore likely to change the functioning of ecosystems. Natural disturbances occur frequently in coastal and estuarine ecosystems, and recent intense anthropogenic activities often significantly reduce ecosystem resilience (Alestra and Schiel, 2015). An important example of such a humaninduced change in coastal and estuarine habitats is sediment deposition. Natural sedimentation is caused by surface runoff from the catchment area or by tidal movements; the former can be intensified by land use change (Thrush et al., 2004). Furthermore, dredging and dumping activities also contribute to sediment deposition, either directly or by creating sediment plumes that subsequently settle down on the seabed (Van Lancker and Baeye, 2015). Such deposition events are expected to alter the productivity of coastal soft-sediment habitats via direct and indirect mechanisms that affect biogeochemical cycling. Firstly, the formation of a physical barrier increases the contribution of anaerobic pathways to the overall decomposition and relocates the re-oxidation of reduced solutes upwards (Colden and Lipcius, 2015; Hohaia et al., 2014). Under these circumstances, reduced solid phases would only oxidize when sediment reworking or irrigation of large burrows by macrofauna brings them to the oxic layer. Macrofauna plays an important role in the biogeochemical cycling of soft sediments through sediment particle mixing (i.e. bioturbation) and the assisted transfer of solutes through the sediment (i.e. bio-irrigation) (Braeckman et al., 2010, 2014; Van Colen et al., 2012; Thrush et al., 2006). Though both processes are interrelated and sometimes grouped under the umbrella term "bioturbation" (Kristensen et al., 2012), we opted to use them as separate concepts, in order to clearly distinguish between particle reworking and solute transfer. Bioturbation and bio-irrigation can be significantly altered under increased sediment deposition through changes in macrobenthic densities (Alves et al., 2017) or behaviour (Rodil et al., 2011). For example, sessile organisms that live attached to the substratum or in tubes often have a limited capacity to escape burial, and suspension feeders risk clogging of their feeding apparatus (Ellis et al., 2002; Lohrer et al., 2004). Secondly, macrofauna activities can interfere with the deposition induced physical barrier at the sedimentwater interface. Sediment deposition induced loss of macrofauna species density and change of behaviour therefore represents a second, more indirect pathway of how deposition events can alter ecosystem functioning.

Tidal flats are dynamic, sedimentary environments that naturally undergo processes of erosion and deposition. Per tidal cycle, different elevation changes have been observed, e.g. from decreases of $3.3 \mathrm{~mm}$ in the Yangtze estuary (China) to increases of $6 \mathrm{~mm}$ in the estuary of the Seine (France) (Deloffre et al., 2007; Shi et al., 2012). Our study was performed on a mudflat in the estuary of the river Scheldt (Belgium, the Netherlands), which is characterized by its meso- to macrotidal regime and well-mixed water column. Sediment input from the river basin is relatively low and sand extraction and sea level rise lead to a net export of sediment from the estuary (De Vriend et al., 2011). Sediment accretion on the estuary's tidal flats can amount to about $2 \mathrm{~cm} \mathrm{yr}^{-1}$ (Weerman et al., 2011; Widdows et al., 2004), which suggests that natural sedimentation on the intertidal mudflats is unlikely to exceed even a few millimetres per tidal cycle. More extreme changes in the bed level of mudflats can, however, happen during storm events, either by erosion of the top centimetres of the sediment or by deposition of new sediment (Hu et al., 2015; Marion et al., 2009). Besides natural processes, anthropogenic factors influencing sedimentation are prominent in the estuary, among which dredging in the main channels to ensure access to the port of Antwerp and dumping of the dredged material to retain sediment within the estuary are the most important (Jeuken and Wang, 2010; Meire et al., 2005). Most of this dredged sediment is disposed of near shoals and tidal flats and can thus affect the intertidal ecosystem (Bolam and Whomersley, 2005; De Vriend et al., 2011; Zheng, 2015). The effects of sediment deposition on taxonomic diversity (Thrush et al., 2003), behaviour (Hohaia et al., 2014; Townsend et al., 2014), and ecosystem functioning (Larson and Sundbäck, 2012; Montserrat et al., 2011) have recently received considerable attention. However, to the best of our knowledge, no integrated study of the effect of sediment deposition on the benthic processes that drive biogeochemical cycling (i.e. bioturbation and bio-irrigation) has hitherto been published. This study therefore aims to obtain a mechanistic understanding of sediment deposition effects on ecosystem functioning by experimentally assessing the impacts of deposition events of different magnitude (i.e. thickness of the deposited sediment layer) on benthic community diversity and biological traits (i.e. diversity, densities), benthic processes (i.e. bioturbation and bio-irrigation), and biogeochemical cycling in an intertidal soft-sediment habitat. We hypothesize that sediment deposition reduces oxygen availability to the community underneath, consequently affecting the survival of the macrobenthos and inducing escaping behaviour (Riedel et al., 2008; Villnäs et al., 2012). This may influence biogeochemical cycling by affecting bioturbation or bio-irrigation (Van Colen et al., 2012; Renz and Forster, 2014).

\section{Materials and methods}

\subsection{Sample collection and experimental set-up}

Samples were collected in March 2015 at the Paulina mudflat (SW Netherlands), which is located along the southern shore of the polyhaline part of the Scheldt estuary $\left(51^{\circ} 21.02^{\prime} \mathrm{N}\right.$, $\left.3^{\circ} 43.78^{\prime} \mathrm{E}\right)$. The Scheldt estuary experiences a number of 
human-induced processes that can increase sediment deposition on tidal flats, among which dredging and the local deposition of dredged sediments at the edges of tidal flats are some of the most important examples (De Vriend et al., 2011; van der Wal et al., 2011). The Paulina mudflat harbours a functionally rich benthic macrofaunal community that is numerically dominated by polychaetes (Van Colen et al., 2008, 2010).

Twenty-four cylindrical sediment corers $(10 \mathrm{~cm}$ inner diameter, $29 \mathrm{~cm}$ length) were used to randomly collect cores within a $5 \times 5 \mathrm{~m}$ patch of sediment, consisting of $46 \pm 0.9 \%$ mud $(<63 \mu \mathrm{m}), 22.9 \pm 0.4 \%$ very fine sand $(63-125 \mu \mathrm{m}), 21.7 \pm 0.6 \%$ fine sand $(125-250 \mu \mathrm{m})$, and $9.4 \pm 0.2 \%$ medium sand $(250-500 \mu \mathrm{m})$. Additional sediment for the experimental deposition treatments had been collected at the same site a few days before the start of the experiment. This additional sediment was sieved over a $1 \mathrm{~mm}$ mesh, dried in the lab at $60^{\circ} \mathrm{C}$, heated in a muffle furnace at $500{ }^{\circ} \mathrm{C}$ to remove all organic matter (so that treatment effects could be unambiguously assigned to the physical smothering effect), rinsed with demineralized water, and subsequently sieved again.

All cores were cut to $9 \mathrm{~cm}$, and each core was subsequently subjected to one of four treatments, each with six replicates. Each treatment except the control (T0) consisted of the application of a layer of the pre-treated sediment with a thickness of 1 (T1), 2 (T2) or $5 \mathrm{~cm}$ (T5), including a $0.5 \mathrm{~cm}$ thick frozen mud cake containing Magenta luminophores (Environmental Tracing Systems Ltd., Helensburgh, UK; median grain size $65 \mu \mathrm{m}$ ) and pre-treated sediment in a $1: 1 \mathrm{vol}$ ume : volume ratio to measure bioturbation activity. The control treatment only received a luminophore cake on top of the natural sediment surface. The addition of this mud cake ensured the quantification of particle mixing in these treatments and avoided potential bias between treatments due to species specific responses to the physico-chemical environment created by the mud cake. The addition of a luminophore mud cake on top of the sediment surface in the control treatment did not profoundly affect the natural oxygen fluxes or oxygen penetration depth. Our measured values were comparable in magnitude to those of previous studies in the same habitat and season (Van Colen et al., 2012; Table S1 in the Supplement), and clear bioturbation signs on the sediment surface soon after deposition indicate fast migration to the sedimentwater interface (Fig. S1 in the Supplement).

Seawater from the sampling location $\left(10^{\circ} \mathrm{C}\right.$ and a salinity of 20.3, kept still in barrels in the lab for half a day to allow suspended sediment to sink down) was carefully added on top of each core, up to the top edge of the corer. After addition of the water, the added sediment layers compacted to an average of $1.09 \pm 0.18$ (T1), $1.52 \pm 0.10$ (T2), and $3.75 \pm 0.11 \mathrm{~cm}$ (T5), respectively. The cores were incubated in two tanks under ambient temperature and salinity conditions, filled until half the corer height to buffer for small changes in temperature, and provided with a constant air sup- ply through bubbling underneath the water surface in each core. Each tank had a total capacity of 12 corers and contained three replicates of each treatment. Oxygen did not penetrate deeper than the lower boundary of the deposited sediment layers in the deposition treatments; hence, the sediment deposition created a physical barrier at the sediment-water interface prohibiting (passive) exchange of dissolved oxygen between the sampled community and the water column at the onset of the experiment (Table S1). The experiment ran for 15 days, with different measurements taking place during this period. After letting the cores rest to regain biogeochemical equilibria, sediment oxygen profiles were measured on days 7 and 8 and oxygen fluxes on day 12, followed by 2 days of measuring bio-irrigation and a final day on which the cores were sliced for further analysis.

\subsection{Biogeochemical cycling}

For the SCOC measurements, all cores were equipped with a magnetic stirring ring and sealed with an airtight lid, fitted with two Luer stopcocks enabling the sampling of the overlying water for the measurement of sediment-water column exchange of oxygen. During $5 \mathrm{~h}$ (approximately $1 \mathrm{~h}$ intervals), $40 \mathrm{~mL}$ water samples were collected through one of the stopcocks using a glass syringe. Replacement water was added by opening the second stopcock and allowing tank water to flow in. The water samples were treated with Winkler reagents (Parsons et al., 1984) and stored at $4{ }^{\circ} \mathrm{C}$ until Winkler titration (Mettler Toledo G20, DGi 101-Mini oxygen electrode; LabX Light Titration software, Columbus, OH, USA). Sediment community oxygen consumption rates (SCOC) were then calculated from the linear decline in oxygen concentration, according to Eq. (1):

$\mathrm{SCOC}=-\frac{\mathrm{d} C}{\mathrm{~d} t} \frac{V}{A}$,

where $\frac{\mathrm{d} C}{\mathrm{~d} t}$ is the change in oxygen concentration in the overlying water (in mmol $\mathrm{L}^{-1} \mathrm{~d}^{-1}$ ), $V$ is the volume of the overlying water (in L), and $A$ is the sediment surface area (in $\mathrm{m}^{2}$ ).

For the measurement of diffusive oxygen uptake (DOU), vertical sediment oxygen profiles were measured with a Unisense OX100 Clark-type needle electrode (Unisense, Aarhus, Denmark). Three profiles were measured in each core and the result was averaged to account for spatial variability in the sediment. The DOU could then be calculated by multiplying the negative slope of the initial decrease in oxygen concentration by its diffusion coefficient (Glud, 2008). The oxygen uptake that could be attributed to macrofaunal respiration was calculated by the formulae described in $\mathrm{Ma}-$ haut et al. (1995), in which ash-free dry weight (AFDW), calculated from wet weights of the animals (see further), is used to calculate respiration rates:

$R=0.0174 W^{0.0844}$ 
where $R$ is the respiration rate in $\mathrm{mg} \mathrm{Cd}^{-1}$ and $W$ the mean individual AFDW in $\mathrm{mgC}$. The amount of carbon was estimated to be $50 \%$ for all species (Wijsman et al., 1999). Since this formula is only valid for the temperature range of 15 to $20^{\circ} \mathrm{C}$, a $Q_{10}$ of 2 was then assumed to correct the bias, and a respiratory quotient of 0.85 was used to calculate the oxygen consumption, here characterized as faunal uptake (FU; Braeckman et al., 2010; Mahaut et al., 1995). The remaining part of SCOC, after subtraction of DOU and FU, is the macrofauna-mediated oxygen uptake (MMU), caused indirectly by stimulation of aerobic remineralization by macrofaunal bioturbation and irrigation.

\subsection{Bio-irrigation and bioturbation}

One day after the oxygen flux measurements, water was siphoned off from each core and replaced by a $\mathrm{NaBr}$-seawater mixture to assess bio-irrigation. The $\mathrm{NaBr}$ solution had the same density as the seawater; both were mixed to obtain a solution with a final concentration of $0.1 \mathrm{M} \mathrm{NaBr}$. The solution was added with $100 \mathrm{~mL}$ syringes on all cores until as close as possible to the edge, which amounted to $700 \mathrm{~mL}$ for T0, T1, and T2 and $600 \mathrm{~mL}$ for T5. A first sample of $2 \mathrm{~mL}$ was taken immediately after adding the mixture and subsequently after $1,2,18$, and $21 \mathrm{~h}$. The bromide concentrations were measured with ion chromatography and used to calculate bio-irrigation rates:

$Q=-\frac{V_{\mathrm{OW}}}{C_{\mathrm{OW}}-C_{\mathrm{PW}}} \frac{\mathrm{d} C_{\mathrm{OW}}}{\mathrm{d} t}$,

where $Q$ is the bio-irrigation rate, $V_{\mathrm{OW}}$ is the volume of the overlying water in $\mathrm{L}, C_{\mathrm{OW}}$ is the initial concentration of bromide in the overlying water $\left(\mathrm{mol} \mathrm{L}^{-1}\right), C_{\mathrm{PW}}$ is the bromide concentration in the pore water, and $\frac{\mathrm{d} C \mathrm{OW}}{\mathrm{d} t}$ is the change of bromide concentration in the overlying water over time (in mol L ${ }^{-1} \mathrm{~d}^{-1}$ ). For $C_{\mathrm{PW}}$, an estimation was made by measuring the background concentration in untreated seawater.

On the 14th day of the experiment, the remaining water was siphoned off the cores, which were subsequently sliced per $5 \mathrm{~mm}$ from the top until $2 \mathrm{~cm}$ into the natural sediment. Deeper slices were cut at a thickness of $10 \mathrm{~mm}$. The sediment in each slice was thoroughly homogenized, after which 5 to $10 \mathrm{~mL}$ was sampled and frozen at $-20^{\circ} \mathrm{C}$, awaiting further processing for the quantification of bioturbation.

The samples were subsequently dried for $48 \mathrm{~h}$ at $60^{\circ} \mathrm{C}$; water was then carefully added again, after which the sediment was spread open in a $55 \mathrm{~mm}$ inner diameter Petri dish. Each sample was photographed under UV light ( $365 \mathrm{~nm}$ peak wavelength) and luminophores were counted with computer scripts in Matlab v8.1 (MathWorks Inc., 2013) and R (R Development Core Team, 2013). A vertical profile of luminophore pixel counts was constructed for each sediment core and additional $\mathrm{R}$ scripts were used to fit the profiles to a non-local bioturbation model from which the biodiffusion coefficient $\left(D_{\mathrm{b}}^{\mathrm{NL}}\right.$, in $\left.\mathrm{cm}^{2} \mathrm{~d}^{-1}\right)$ was calculated (Wheatcroft et al., 1990). Since luminophores were only applied on the sediment-water interface, the measured profiles represent disturbance of the surface by bioturbating fauna, rather than providing a total picture of the sediment mixing underneath the surface.

\subsection{Macrofauna}

The remaining 85 to $90 \%$ of the sediment was rinsed over a $500 \mu \mathrm{m}$ mesh-sized sieve to collect the macrofauna. The animals were stained with a rose bengal dye in order to facilitate the identification. Organisms were identified to species level, except for Oligochaeta and Spio sp. After identification, all animals were weighed to assess their biomass. The ash-free dry weight (AFDW) was determined by using conversion factors from wet weights (Sistermans et al., 2006). Biomasses were used to calculate the faunal respiration (Mahaut et al., 1995).

\subsection{Data analysis}

Diversity indices (Shannon-Wiener diversity $H^{\prime}$ (base $e$ ), Pielou's evenness $J^{\prime}$ and species richness $S$ ) were calculated with Primer v6.1 (Clarke and Gorley, 2006). All taxa were assigned to functional groups based on their motility (from M1 - living fixed in a tube - till M4 - free three-dimensional movement through a burrow system) and sediment reworking activity (surficial modifiers, biodiffusors, upward conveyors, and downward conveyors), according to Queirós et al. (2013). All downward conveyors in our study were also classified as upward conveyors, since they can perform both sediment reworking activities

Differences between the treatments for all biotic and abiotic variables, including all species' densities, were first tested by a two-way ANOVA, where "Tank" and "Treatment" were used as factors. Since these analyses demonstrated that there were no interaction effects of tank and treatment, a blocked-design ANOVA was applied, with "Tank" as the blocking factor. A Tukey HSD test was used for pairwise comparisons in case of a significant treatment effect. In case the assumptions of normality (tested with a ShapiroWilk test) and homogeneity of variances (assessed with Levene's test) for ANOVA were not met, a fourth-root transformation was performed on the data. Differences in community composition were tested with multivariate two-way permutational analysis of variance (PERMANOVA; Anderson et al., 2008). A similarity percentages analysis (SIMPER), based on a Bray-Curtis similarity matrix, was used to determine the species which contributed most to the differences between treatments. When a significant treatment effect was found, pairwise PERMANOVA tests were performed in order to detect differences between the treatments. The PERMANOVA tests were followed by a PERMDISP test to define whether the found effects are influenced by heterogeneity of multivariate dispersions. 

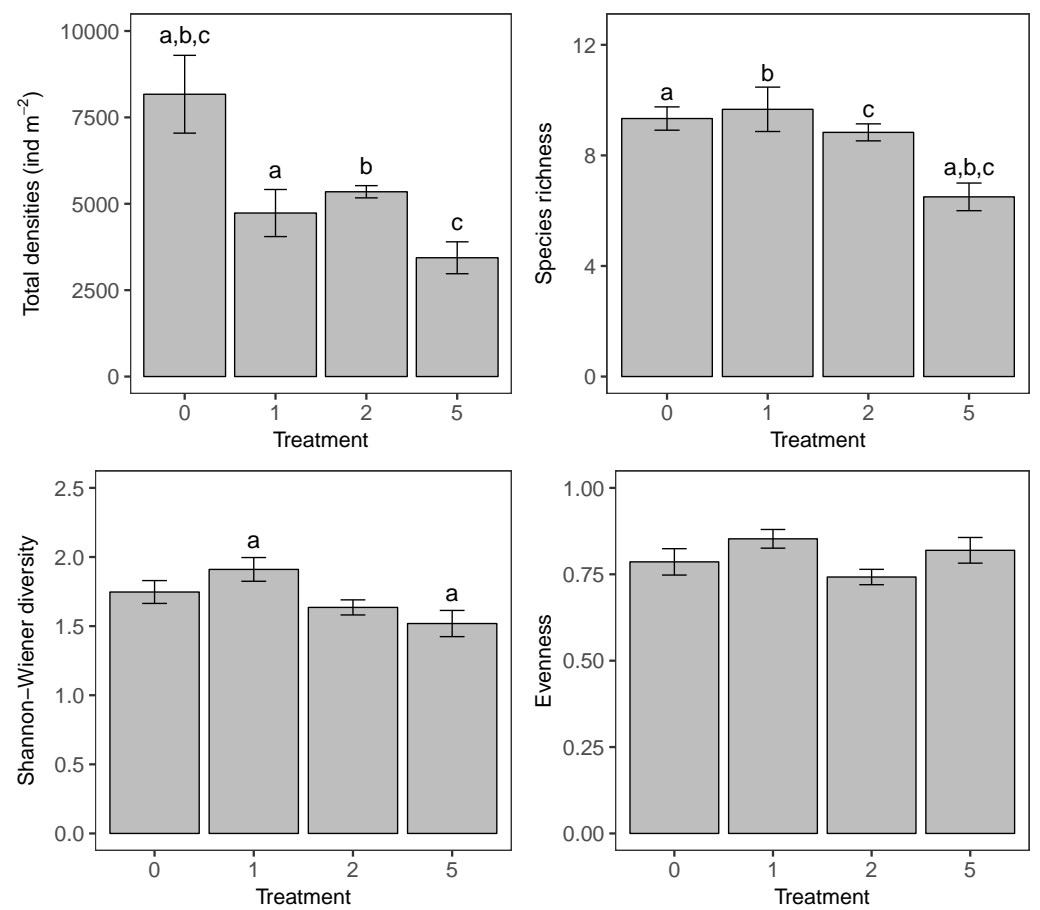

Figure 1. Bar charts representing total macrofaunal densities (ind $\mathrm{m}^{-2}$ ), species richness, Shannon-Wiener diversity, and Pielou's evenness per treatment. Error bars represent mean \pm standard error; letters above the error bars indicate pairwise significant differences. The four treatments represent the thickness of the applied sediment layer (in $\mathrm{cm}$ ).

Linear regressions were applied to find relationships between the different response variables. Most importantly, relationships were identified between ecosystem functioning (SCOC), benthic processes (bioturbation, bio-irrigation) and the various biotic variables, including densities of all individual species. Further regression tests investigated the contribution of individual species to the density-ecosystem functioning relationship by using the densities of all taxa as predictor variables. The optimal model was selected via stepwise combined backward and forward selection. The variance inflation factor (VIF) was used to determine multicollinearity of the predictor variables. All assumptions for linear regression were tested on the residuals and met (no outliers and normal distribution).

All statistical analyses were performed with $\mathrm{R}$ v3.0.3 (R Development Core Team, 2013), except the PERMANOVA and SIMPER tests, for which Primer v6.1 with the PERMANOVA+ add-on was used (Clarke and Gorley, 2006).

\section{Results}

\subsection{Macrofauna}

Sediment deposition affected community structure, with the community present in T5 differing significantly from the control (two-factor PERMANOVA pseudo- $F=2.457, P=$
0.013; pairwise comparisons T0-5: $P=0.010$ ). The PERMDISP test was not significant for either the main test or the pairwise comparison (main test $F=0.858, P=0.5795$; T0T5: $P=0.6282)$. Species that contributed most to the dissimilarity in community structure between these treatments were Aphelochaeta marioni and Oligochaeta spp. (Table 1). Densities of Polydora cornuta and Scrobicularia plana (Table 2) were significantly lower in T5 (Tables 3,4 ). The control community had significantly higher total densities than the other communities, while lowest Shannon-Wiener diversity and species richness were found for the T5 community (Fig. 1, Tables 3, 4). Community evenness did not differ significantly among treatments.

In general, changes in macrobenthic community composition mirrored differential responses of specific motility and sediment reworking traits (Fig. 2, Table 3). Densities of the two groups of organisms with lowest motility were negatively affected by the applied treatments while densities of more motile species were not significantly different among treatments (Fig. 2a). The density of tube-building organisms (M1) decreased gradually with the thickness of the deposited sediment, whereas densities of species with limited movement (M2) were impaired by all sediment deposition treatments, irrespective of their magnitude (Fig. 2a).

All sediment reworking groups were affected by the deposition (Fig. 2b). For surficial modifiers, all treatments showed lower densities compared to the control, and for upward con- 
Table 1. The three species with highest cumulative contribution $(>50 \%)$ to the total dissimilarity between treatments*. The first column shows the treatments being compared (e.g. T0-1: a comparison between treatments T0 and T1).

\begin{tabular}{|c|c|c|c|}
\hline Treatments & Average dissimilarity & Species & Cumulative contribution \\
\hline \multirow[t]{3}{*}{ T0-1 } & 42.14 & Aphelochaeta marioni & $37.61 \%$ \\
\hline & & Oligochaeta spp. & $59.97 \%$ \\
\hline & & Polydora cornuta & $65.83 \%$ \\
\hline \multirow[t]{3}{*}{ T0-2 } & 36.49 & Aphelochaeta marioni & $37.86 \%$ \\
\hline & & Oligochaeta spp. & $54.76 \%$ \\
\hline & & Polydora cornuta & $62.00 \%$ \\
\hline \multirow[t]{3}{*}{ T0-5 } & 48.60 & Aphelochaeta marioni & $35.25 \%$ \\
\hline & & Oligochaeta spp. & $57.60 \%$ \\
\hline & & Polydora cornuta & $64.39 \%$ \\
\hline \multirow[t]{3}{*}{$\mathrm{T} 1-2$} & 38.74 & Oligochaeta spp. & $26.49 \%$ \\
\hline & & Aphelochaeta marioni & $52.01 \%$ \\
\hline & & Hediste diversicolor & $60.03 \%$ \\
\hline \multirow[t]{3}{*}{ T1-5 } & 42.42 & Aphelochaeta marioni & $24.20 \%$ \\
\hline & & Oligochaeta spp. & $46.10 \%$ \\
\hline & & Scrobicularia plana & $56.55 \%$ \\
\hline \multirow[t]{3}{*}{$\mathrm{T} 2-5$} & 41.15 & Oligochaeta spp. & $31.12 \%$ \\
\hline & & Aphelochaeta marioni & $56.73 \%$ \\
\hline & & Hediste diversicolor & $65.37 \%$ \\
\hline
\end{tabular}

* Results from a SIMPER analysis.

Table 2. Densities (in ind $\mathrm{m}^{-2}$ ) of all identified taxa in the macrobenthic communities. All values are means \pm standard errors.

\begin{tabular}{lrrrr}
\hline Species & T0 & T1 & T2 & T5 \\
\hline Polychaeta & & & & \\
\hline Aphelochaeta marioni & $3225.54 \pm 724.49$ & $1379.34 \pm 388.17$ & $1570.33 \pm 358.12$ & $1167.14 \pm 267.92$ \\
Eteone longa & $21.11 \pm 21.22$ & $84.88 \pm 42.44$ & $63.66 \pm 28.47$ & $21.11 \pm 21.22$ \\
Hediste diversicolor & $594.18 \pm 107.37$ & $551.74 \pm 121.53$ & $530.52 \pm 129.08$ & $233.43 \pm 60.77$ \\
Heteromastus filiformis & $254.65 \pm 73.51$ & $127.32 \pm 46.49$ & $254.65 \pm 131.50$ & $84.88 \pm 26.84$ \\
Polydora cornuta & $381.97 \pm 131.50$ & $169.77 \pm 53.68$ & $42.44 \pm 26.84$ & $0.00 \pm 0.00$ \\
Pygospio elegans & $297.09 \pm 102.21$ & $148.54 \pm 76.51$ & $169.77 \pm 42.44$ & $0.00 \pm 0.00$ \\
Spio sp. & $21.22 \pm 21.22$ & $0.00 \pm 0.00$ & $0.00 \pm 0.00$ & $0.00 \pm 0.00$ \\
Streblospio benedicti & $63.66 \pm 43.49$ & $0.00 \pm 0.00$ & $42.44 \pm 26.84$ & $0.00 \pm 0.00$ \\
Oligochaeta spp. & $2058.40 \pm 343.88$ & $997.37 \pm 271.92$ & $1846.20 \pm 251.98$ & $933.71 \pm 295.26$ \\
\hline Bivalvia & & & & $0.00 \pm 0.00$ \\
\hline Cerastoderma edule & $42.44 \pm 26.84$ & $42.44 \pm 26.84$ & $127.32 \pm 32.87$ & $148.54 \pm 51.11$ \\
Limecola balthica & $63.66 \pm 43.49$ & $233.43 \pm 76.51$ & $106.10 \pm 51.11$ & $106.10 \pm 83.28$ \\
Scrobicularia plana & $403.19 \pm 60.77$ & $381.97 \pm 80.53$ & & \\
\hline Gastropoda & & & & \\
\hline Hydrobia ulvae & $106.10 \pm 51.11$ & $169.77 \pm 53.68$ & $148.54 \pm 60.77$ & $212.21 \pm 117.00$ \\
\hline Crustacea & & & & \\
\hline Bathyporeia pilosa & $0.00 \pm 0.00$ & $21.22 \pm 21.22$ & $0.00 \pm 0.00$ & $21.22 \pm 21.22$ \\
Cyathura carinata & $636.62 \pm 103.96$ & $424.41 \pm 78.26$ & $445.63 \pm 107.79$ & $509.30 \pm 65.75$ \\
\hline & & & &
\end{tabular}


Table 3. Statistical factors from two-factor blocked ANOVA tests with "Treatment" (4 levels) and "Tank" (2 levels) as factors. M1 until M4 stand for motility classes, as defined by Solan et al. (2004) (M1: living fixed in a tube; M2: sessile, but not fixed in a tube; M3: slow movement through the sediment; M4: free movement in a burrow system). Significant pairwise differences between treatments are given in the table. All results for species and functional groups are given for densities.

\begin{tabular}{|c|c|c|c|c|}
\hline Source & $F$ value & $P$ & Pairwise significance & Transformation \\
\hline M1 & 12.221 & $<0.001^{*}$ & $0-5,1-5,2-5$ & Fourth root \\
\hline M2 & 7.013 & $0.002^{*}$ & $0-1,0-2,0-5$ & \\
\hline M3 & 3.05 & 0.054 & & \\
\hline M4 & 2.284 & 0.112 & & \\
\hline Surficial modifiers & 6.087 & $0.004^{*}$ & $0-1,0-2,0-5$ & \\
\hline Biodiffusors & 4.336 & $0.017^{*}$ & $0-5$ & \\
\hline Upward conveyors & 10.112 & $<0.001^{*}$ & $0-1,0-2,0-5$ & \\
\hline Downward conveyors & 24.371 & $<0.001^{*}$ & $0-5,1-5,2-5$ & Fourth root \\
\hline \multicolumn{5}{|l|}{ Polychaeta } \\
\hline Aphelochaeta marioni & 4.648 & $0.013^{*}$ & $0-1,0-5$ & \\
\hline Eteone longa & 1.103 & 0.372 & & \\
\hline Hediste diversicolor & 2.284 & 0.112 & & \\
\hline Heteromastus filiformis & 1.154 & 0.353 & & \\
\hline Polydora cornuta & 7.254 & $0.002^{*}$ & $0-2,0-5,1-5$ & Fourth root \\
\hline Pygospio elegans & 5.155 & $0.009^{*}$ & $0-5,2-5$ & Fourth root \\
\hline Spio sp. & 1 & 0.414 & & \\
\hline Streblospio benedicti & 1.879 & 0.167 & & \\
\hline Oligochaeta spp. & 3.873 & $0.026^{*}$ & None & \\
\hline \multicolumn{5}{|l|}{ Bivalvia } \\
\hline Cerastoderma edule & 1.583 & 0.226 & & \\
\hline Limecola balthica & 1.939 & 0.158 & & \\
\hline Scrobicularia plana & 5.337 & $0.008^{*}$ & $0-2,0-5$ & \\
\hline \multicolumn{5}{|l|}{ Gastropoda } \\
\hline Peringia ulvae & 0.329 & 0.804 & & \\
\hline \multicolumn{5}{|l|}{ Crustacea } \\
\hline Bathyporeia pilosa & 0.704 & 0.561 & & \\
\hline Cyathura carinata & 1.055 & 0.391 & & \\
\hline$D_{\mathrm{b}}^{\mathrm{NL}}$ & 4.826 & $0.012^{*}$ & $0-1,1-2,1-5$ & Fourth root \\
\hline$Q^{\mathrm{D}}$ & 4.177 & $0.020^{*}$ & $1-5$ & \\
\hline SCOC & 3.358 & $0.041^{*}$ & $0-5$ & \\
\hline DOU & 2.178 & 0.124 & & \\
\hline FU & 0.869 & 0.475 & & \\
\hline Total density & 8.346 & $0.001^{*}$ & $0-1,0-2,0-5$ & \\
\hline$H^{\prime}$ & 4.983 & $0.010^{*}$ & $1-5$ & \\
\hline$J^{\prime}$ & 2.594 & 0.083 & & \\
\hline Species richness & 6.697 & $0.003^{*}$ & $0-5,1-5,2-5$ & \\
\hline
\end{tabular}

veyors T5 was significantly lower than all other treatments (Tables 3,4). The density of biodiffusors was only significantly reduced in T5 compared to the control (Fig. 2b).

Activity of the macrofauna (bioturbation and bioirrigation) was significantly affected by the deposition treatments (Table 4). Bioturbation activity was significantly higher in $\mathrm{T} 1$ than in all other treatments (Tables 3,4), and was lowest in T5. While the biodiffusion coefficient $D_{\mathrm{b}}^{\mathrm{NL}}$ reached average values in the control treatment, it rose sig- nificantly in T1 and dropped again in T2 and T5 (Fig. 3a). A similar pattern was observed for bio-irrigation, but here we only found a significant difference between $\mathrm{T} 1$ and $\mathrm{T} 5$ (Fig. 3b).

\subsection{Ecosystem functioning}

Sediment community oxygen consumption (SCOC) decreased with increasing thickness of the applied sediment 
Table 4. Overview of the $p$ values for all pairwise tests (Tukey post hoc test), performed when the main test provided significant results. All results for species and functional groups represent densities.

\begin{tabular}{lrrrrrr}
\hline Source & T0-T1 & T0-T2 & T0-T5 & T1-T2 & T1-T5 & T2-T5 \\
\hline M1 & 0.466 & 0.312 & $<0.001^{*}$ & 0.990 & 0.0028 & $0.004^{*}$ \\
M2 & $0.017^{*}$ & $0.015^{*}$ & $0.002^{*}$ & 1.000 & 0.805 & 0.838 \\
Surficial modifiers & $0.033^{*}$ & $0.013^{*}$ & $0.006^{*}$ & 0.974 & 0.850 & 0.980 \\
Upward conveyors & $0.016^{*}$ & $0.036^{*}$ & $<0.001^{*}$ & 0.982 & 0.186 & 0.095 \\
Downward conveyors & 0.102 & 0.289 & $<0.001^{*}$ & 0.927 & $<0.001^{*}$ & $<0.001^{*}$ \\
Biodiffusors & 0.156 & 0.959 & $0.024^{*}$ & 0.344 & 0.780 & 0.067 \\
Aphelochaeta marioni & $0.035^{*}$ & 0.065 & $0.017^{*}$ & 0.989 & 0.986 & 0.913 \\
Polydora cornuta & 0.896 & $0.044^{*}$ & $0.003^{*}$ & 0.167 & $0.014^{*}$ & 0.611 \\
Pygospio elegans & 0.463 & 0.981 & $0.010^{*}$ & 0.687 & 0.194 & $0.023^{*}$ \\
Scrobicularia plana & 0.997 & $0.039^{*}$ & $0.039^{*}$ & 0.060 & 0.060 & 1.000 \\
$D_{\mathrm{b}}^{\text {NL }}$ & $0.016^{*}$ & 0.949 & 0.087 & $0.048^{*}$ & $0.032^{*}$ & 0.997 \\
$Q$ & 0.104 & 0.705 & 0.794 & 0.541 & $0.016^{*}$ & 0.222 \\
SCOC & 0.338 & 0.145 & $0.030^{*}$ & 0.951 & 0.552 & 0.850 \\
Total density & $0.011^{*}$ & $0.043^{*}$ & $0.001^{*}$ & 0.921 & 0.560 & 0.240 \\
$H^{\prime}$ & 0.430 & 0.721 & 0.171 & 0.076 & $0.007^{*}$ & 0.691 \\
Species richness & 0.973 & 0.918 & $0.009^{*}$ & 0.714 & $0.003^{*}$ & $0.035^{*}$ \\
\hline
\end{tabular}

Significant $p$ values $(P<0.05)$ are indicated with *.

(a)

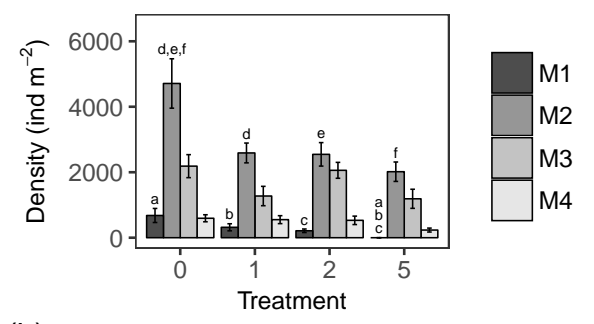

(b)

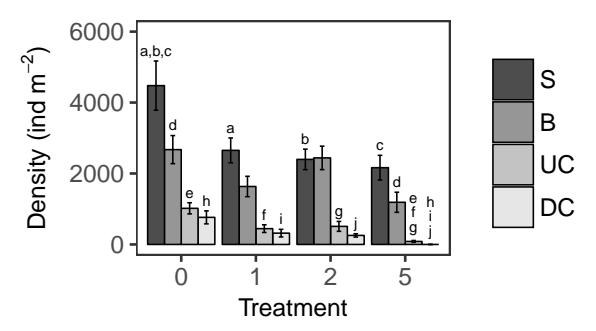

Figure 2. (a) Bar chart showing the densities of the four motility classes per treatment, in ind $\mathrm{m}^{-2}$. M1: organisms living fixed in a tube; M2: sessile, but not fixed in a tube; M3: slowly moving organisms; M4: free movement through a burrow system. (b) Bar chart showing the densities in ind $\mathrm{m}^{-2}$ of the four main functional groups, based on sediment reworking activity. S: Surficial modifiers; B: biodiffusors; UC: upward conveyors; DC: downward conveyors. Error bars represent mean \pm standard error; letters above the error bars indicate pairwise significant differences. The four treatments represent the thickness of the applied sediment layer (in $\mathrm{cm}$ ). layer, ranging from $54.68 \pm 5.35 \mathrm{mmol} \mathrm{m}^{-2} \mathrm{~d}^{-1}$ in the control to $46.79 \pm 3.53 \mathrm{mmol} \mathrm{m}^{-2} \mathrm{~d}^{-1}$ in $\mathrm{T} 1$ and $44.37 \pm 3.52$ mmol m${ }^{-2} \mathrm{~d}^{-1}$ in $\mathrm{T} 2$ to $40.68 \pm 3.60 \mathrm{mmol} \mathrm{m}^{-2} \mathrm{~d}^{-1}$ in T5. Only T5 differed significantly from the control $(P=$ 0.030) (Fig. 3c, Table 4). Faunal respiration (FU) accounted for $2.67 \pm 1.01 \%$ of the total SCOC in $\mathrm{T} 0,3.64 \pm 1.64 \%$ in $\mathrm{T} 1,1.75 \pm 0.30 \%$ in $\mathrm{T} 2$, and $1.99 \pm 0.41 \%$ in $\mathrm{T} 5$, while the DOU amounted for $18.55 \pm 2.64 \mathrm{mmol} \mathrm{m}^{-2} \mathrm{~d}^{-1}$ in $\mathrm{T} 0,13.71 \pm 1.80 \mathrm{mmol} \mathrm{m}^{-2} \mathrm{~d}^{-1}$ in $\mathrm{T} 1,11.56 \pm 1.79$ mmol m${ }^{-2} \mathrm{~d}^{-1}$ in $\mathrm{T} 2$, and $16.37 \pm 1.84 \mathrm{mmol} \mathrm{m}^{-2} \mathrm{~d}^{-1}$ in $\mathrm{T} 5$. Neither DOU nor FU showed any significant changes between treatments (Table 4), demonstrating the importance of macrofauna-mediated oxygen uptake (MMU) in the patterns of total SCOC.

Multiple linear regression showed that the variability in SCOC was significantly related to total macrofaunal density and $D_{\mathrm{b}}^{\mathrm{NL}}$, explaining together $54.4 \%$ of the variability in SCOC $(P<0.001)$. When total density was divided over the functional groups, we found significant relationships with $D_{\mathrm{b}}^{\mathrm{NL}}$ and motility groups $\mathrm{M} 2$ and M3 $(P=$ $\left.0.001 ; R^{2}=0.53\right)$, and with surficial modifiers and biodiffusors $\left(P<0.001 ; R^{2}=0.56\right)$. Other variables of community diversity (Shannon-Wiener diversity, species richness, and Pielou's evenness) were not significant predictors of ecosystem functioning. While no single species was found to contribute significantly to $D_{\mathrm{b}}^{\mathrm{NL}}$, a combination of several species contributed significantly to the variability in SCOC $\left(P<0.001 ; R^{2}=0.56\right)$. The taxa with a significant contribution were A. marioni and Cyathura carinata (Table 5). The statistically optimal model for bio-irrigation included Hediste diversicolor and $P$. cornuta as positive contributors to this process $\left(P<0.001 ; R^{2}=0.73\right)$ (Table 5). 
Table 5. Linear regressions of sediment community oxygen consumption (SCOC) against sets of species (or functional group) densities, ecosystem processes (bio-irrigation, $Q$; bioturbation, $D_{\mathrm{b}}^{\mathrm{NL}}$ ), and bio-irrigation against the densities of species. Only significant models ( $P$ (slope) < 0.05) were considered. M2 and M3 are motility classes as defined by Solan et al. (2004); M2: sessile, but not fixed in a tube; M3: slow movement through the sediment.

\begin{tabular}{|c|c|c|c|}
\hline Response/predictor & Regression equation & $R^{2}$ & $P$ \\
\hline \multicolumn{4}{|l|}{ SCOC } \\
\hline $\begin{array}{l}x_{1}: \text { total density } \\
x_{2}: D_{\mathrm{b}}^{\mathrm{NL}}\end{array}$ & $y=3.35 \times 10^{-3} x_{1}+1.03 \times 10^{2} x_{2}+25.6$ & 0.544 & $\begin{array}{l}0.0001 \\
0.0224\end{array}$ \\
\hline \multicolumn{4}{|l|}{ SCOC } \\
\hline $\begin{array}{l}x_{1}: \mathrm{M} 2 \\
x_{2}: \mathrm{M} 3 \\
x_{3}: D_{\mathrm{b}}^{\mathrm{NL}}\end{array}$ & $y=3.16 \times 10^{-3} x_{1}+5.43 \times 10^{-3} x_{2}+1.02 \times 10^{2} x_{3}$ & 0.529 & $\begin{array}{l}0.0176 \\
0.0404 \\
0.0260 \\
\end{array}$ \\
\hline \multicolumn{4}{|l|}{$\mathrm{SCOC}$} \\
\hline $\begin{array}{l}x_{1}: \text { surficial modifiers } \\
x_{2}: \text { biodiffusors } \\
x_{3}: D_{\mathrm{b}}^{\mathrm{NL}}\end{array}$ & $y=2.92 \times 10^{-3} x_{1}+5.63 \times 10^{-3} x_{2}+1.05 \times 10^{2} x_{3}$ & 0.557 & $\begin{array}{l}0.0359 \\
0.0135 \\
0.0196 \\
\end{array}$ \\
\hline \multicolumn{4}{|l|}{ SCOC } \\
\hline $\begin{array}{l}x_{1}: \text { A. marioni } \\
x_{2}: \text { C. carinata }\end{array}$ & $y=4.53 \times 10^{-3} x_{1}+2.52 \times 10^{-2} x_{2}+25.9$ & 0.556 & $\begin{array}{l}0.0008 \\
0.0016\end{array}$ \\
\hline \multicolumn{4}{|l|}{$Q$} \\
\hline $\begin{array}{l}x_{1}: \text { A. marioni } \\
x_{2}: \text { H. diversicolor } \\
x_{3}: \text { P. cornuta } \\
x_{4}: \text { P. elegans } \\
x_{5}: \text { S. benedicti }\end{array}$ & $\begin{array}{c}y=-5.76 \times 10^{-6} x_{1}+5.00 \times 10^{-5} x_{2}+3.81 \times 10^{-5} x_{3} \\
-6.33 \times 10^{-5} x_{4}-1.60 \times 10^{-4} x_{5}+2.78 \times 10^{-2}\end{array}$ & 0.730 & $\begin{array}{l}0.0330 \\
0.0002 \\
0.0306 \\
0.0030 \\
0.0068\end{array}$ \\
\hline
\end{tabular}

\section{Discussion}

Our results show that even thin sediment deposits can cause a drop in total macrofaunal density, mainly by impacting the highly abundant surface-dwelling animals with low motility (Figs. 1-2a, b). These animals, which belong to reworking and motility class 2 due to their sessile lifestyle (Solan et al., 2004), lack the capacity to escape the deposited sediment and are not adapted to living in deeper sediment layers (Essink, 1999). Since the oxygen penetration depth never exceeded the thickness of the deposited sediment layer (Table S1), we can assume that oxygen stress was a major driver for the observed decrease in faunal densities. In treatments T1 and T2, oxygen stress was possibly reduced by the increased activity of the macrofauna, due to the animals still being able to disturb the surface and oxygenate the underlying sediment. Hypoxia can induce escaping behaviour in benthic fauna, as observed in our intermediate treatments, and increase mortality when more severe (Riedel et al., 2008; Villnäs et al., 2012).

Being identified as significant contributors to changes in SCOC, surface-dwelling and low-motility animals are expected to show density patterns similar to those of SCOC itself. However, SCOC only gradually declined with increasing thickness of the deposited sediment, and this decrease became significant only in the most extreme treatment (T5). Since DOU proved to be constant over all treatments and macrofaunal respiration was negligible compared to the total oxygen consumption, the observed changes in SCOC could be attributed to oxygen uptake caused indirectly by activity of the benthos (i.e. bioturbation and/or bio-irrigation). However, both bio-irrigation and bioturbation, the latter of which was linearly related to SCOC, showed that activity increased in treatments $\mathrm{T} 1$ and $\mathrm{T} 2$. This activity was likely caused by animals for which we found a linear relationship with bioturbation or bio-irrigation, like $H$. diversicolor, that are highly mobile and can bury upwards towards the surface, thereby partly irrigating the sediment. Hediste diversicolor is a "gallery diffusor", which combines biodiffusion in a dense gallery system with biotransport to the bottoms of the tubes (François et al., 2002; Hedman et al., 2011), as well as a wellknown bio-irrigator (Kristensen and Hansen, 1999; Riisgaard and Larsen, 2005). Its activity can be expected to result in the oxygenation of deeper sediment layers, but this effect was probably not sufficient to counteract the loss of less mobile, surface-dwelling fauna. Consequently, we observed a grad- 
(a)

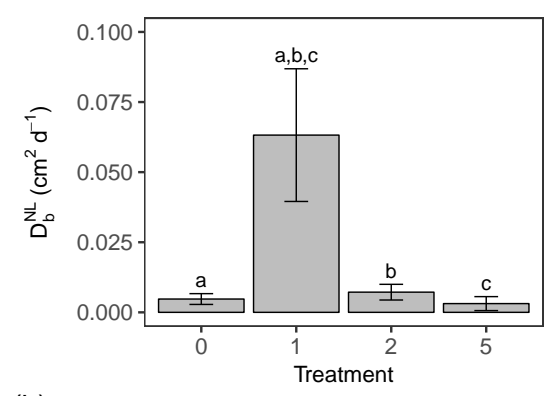

(b)

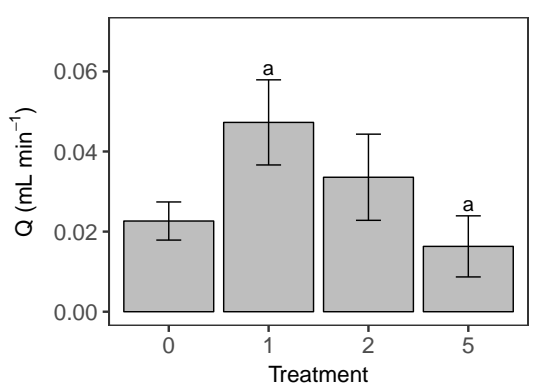

(c)

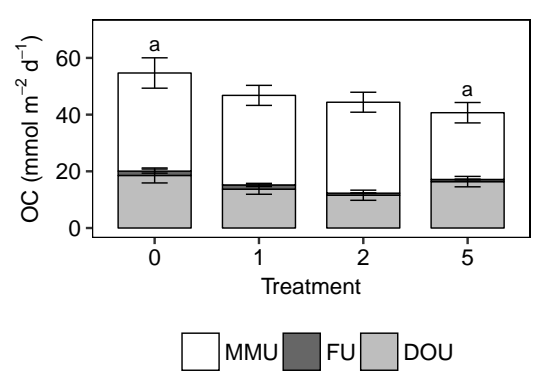

Figure 3. (a) Bar chart representing the mean bioturbation activity (by means of the biodiffusion coefficient $D_{\mathrm{b}}^{\mathrm{NL}}$, in $\mathrm{cm}^{2} \mathrm{~d}^{-1}$ ) per treatment \pm standard error. (b) Bar chart representing the mean bio-irrigation (in $\mathrm{mL} \mathrm{min}^{-1}$ ) per treatment \pm standard error. (c) Bar chart representing the mean oxygen consumption (OC, in mmol m${ }^{-2} \mathrm{~d}^{-1}$ ) per treatment \pm standard error. The different components of total sediment community oxygen consumption (SCOC) are represented in the chart: diffusive oxygen uptake (DOU), with error bars; faunal uptake (FU), with error bars; and the remaining macrofauna-mediated oxygen uptake (MMU). The topmost error bars represent the mean \pm standard error of the total SCOC (= DOU + FU + MMU). Letters above the error bars indicate pairwise significant differences. The four treatments represent the thickness of the applied sediment layer (in $\mathrm{cm}$ ).

ual and significant decline in SCOC, caused by the disappearance of an abundant group of organisms. Upon addition of the thick sediment layer in treatment $\mathrm{T} 5$, species richness dropped significantly and the densities of upward conveyors decreased considerably, hence preventing the transport of organically rich deep sediment to the surface, through the deposited layer. As a result, the deposited sediment essentially functioned as a barrier, preventing contact between sediment organic matter and oxygen in the water column, and therefore reducing microbial degradation and respiration.

Through alterations in functional trait abundances and community composition, natural and anthropogenic disturbances can affect the entire ecosystem functioning (Bolam et al., 2002; Rodil et al., 2011). In the case of burial by sediment deposition, our experiment revealed that SCOC can be affected by causing mortality among surface-dwelling and low motile animals, forming the most abundant functional groups of macrobenthos in our system. Macrobenthic diversity and abundance have been shown to exert some control on the magnitude of solute fluxes across the sediment-water interface (Herman et al., 1999; Thrush et al., 2006). Furthermore, previous studies have shown that functional traits of species can be of great importance to explain ecosystem functioning, rather than or additional to taxonomic diversity (Braeckman et al., 2010; Hooper et al., 2005). Our results highlight the importance of both macrofaunal densities and the functional identity of species. It is clear that taxonomic diversity alone was not sufficient to explain the changes in ecosystem functioning in our experiment, whereas closer inspection of the functional identities provided more realistic insights.

It should be noted that the sediment we used for deposition was completely defaunated and did not contain organic matter. Whereas the aim of using defaunated sediment was to allow a better mechanistic understanding of the consequences of sediment deposition, it does not reflect natural conditions. Dredged material from the bottom of the estuary is much richer in organic material and might lead to different results in a similar experiment. Cottrell et al. (2016) showed that benthic species can have a variable tolerance for changes in the enrichment of the sediment, with higher mortalities under high organic loading (and hence likely stronger impacts on macrofauna-mediated biogeochemical cycling).

\section{Conclusion}

Our experiment revealed new insights into the effects of sediment deposition on the intertidal benthic ecosystem. We found a negative effect on ecosystem functioning, with alterations in macrofauna community structure and activity as the underlying mechanisms. With increasing thickness of the deposited sediment layer, a shift to lower densities of lowmotility and surface-dwelling animals resulted in decreased functioning, even though this was initially dampened by an increased activity of more motile and deeper-living faunas. The latter were responsible for a sustained oxygen penetration through the deposited layer under intermediate treatments, but failed to efficiently do so under more extreme circumstances. It was clear that taxonomic diversity did not suffice to explain changes in functioning, while the functional identity of species did give us important additional insights. 
Data availability. All data will be deposited in the VLIZ Marine Data Archive (http://mda.vliz.be/introduction.php, last access: 2 May 2018).

Supplement. The supplement related to this article is available online at: https://doi.org/10.5194/bg-15-2587-2018-supplement.

Author contributions. SM, LB and CVC devised the experiments. SM and LB carried out the experimental work and collected all data. SM and CVC led the writing of the manuscript, to which all authors contributed.

Competing interests. The authors declare that they have no conflict of interest.

Acknowledgements. Sebastiaan Mestdagh acknowledges a $\mathrm{PhD}$ grant from the Special Research Fund (BOF) of Ghent University. BOF also provided additional financial support through GOA projects 01GA1911W and 01G02617. Ulrike Braeckman and Carl Van Colen are post-doctoral fellows of the Flemish Research Fund (FWO). We would like to thank the laboratory staff at the Marine Biology Research Group of Ghent University who assisted us with our research: Niels Viaene for help during sampling and Bart Beuselinck for grain size analysis. In addition, we want to thank the lab technicians Jan Sinke and Peter van Breugel at the Royal Dutch Institute for Sea Research (NIOZ - Yerseke) for analysing bromide samples.

Edited by: Zhongjun Jia

Reviewed by: two anonymous referees

\section{References}

Alestra, T. and Schiel, D. R.: Impacts of local and global stressors in intertidal habitats: influence of altered nutrient, sediment and temperature levels on the early life history of three habitatforming macroalgae, J. Exp. Mar. Bio. Ecol., 468, 29-36, 2015.

Allen, J. I. and Clarke, K. R.: Effects of demersal trawling on ecosystem functioning in the North Sea: a modelling study, Mar. Ecol.-Prog. Ser., 336, 63-75, 2007.

Alves, R. M. S., Vanaverbeke, J., Bouma, T. J., Guarini, J. M., Vincx, M., and Van Colen, C.: Effects of temporal fluctuation in population processes of intertidal Lanice conchilega (Pallas, 1766) aggregations on its ecosystem engineering, Estuar. Coast. Shelf Sc., 188, 88-98, 2017.

Anderson, M. J., Gorley, R. N., and Clarcke, K. R.: PERMANOVA+ for PRIMER: Guide to software and statistical methods, PRIMER-E, Plymouth, UK, 2008.

Bolam, S. G. and Whomersley, P.: Development of macrofaunal communities on dredged material used for mudflat enhancement: a comparison of three beneficial use schemes after one year, Mar. Pollut. Bull., 50, 40-47, 2005.
Bolam, S. G., Fernandes, T. F., and Huxham, M.: Diversity, biomass, and ecosystem processes in the marine benthos, Ecol Monogr., 72, 599-615, 2002.

Braeckman, U., Provoost, P., Gribsholt, B., Van Gansbeke, D., Middelburg, J. J., Soetaert, K., Vincx, M., and Vanaverbeke, J.: Role of macrofauna functional traits and density in biogeochemical fluxes and bioturbation, Mar. Ecol.-Prog. Ser., 399, 173-186, 2010.

Braeckman, U., Foshtomi, M. Y., Van Gansbeke, D., Meysman, F., Soetaert, K., Vincx, M., and Vanaverbeke, J.: Variable importance of macrofaunal functional biodiversity for biogeochemical cycling in temperate coastal sediments, Ecosystems, 17, 720 737, 2014.

Cardinale, B. J., Duffy, J. E., Gonzalez, A., Hooper, D. U., Perrings, C., Venail, P., Narwani, A., Mace, G. M., Tilman, D., Wardle, D. A., Kinzig, A. P., Daily, G. C., Loreau, M., Grace, J. B., Larigauderie, A., and Srivastava, D. S.: Biodiversity loss and its impact on humanity, Nature, 486, 59-67, 2012.

Clarke, K. R. and Gorley, R. N.: PRIMER v6: user manual/tutorial, PRIMER-E, Plymouth, UK, 2006.

Colden, A. M. and Lipcius, R. N.: Lethal and sublethal effects of sediment burial on the eastern oyster Crassostrea virginica, Mar. Ecol.-Prog. Ser., 527, 105-117, 2015.

Cottrell, R. S., Black, K. D., Hutchison, Z. L., and Last, K. S.: The influence of organic material and temperature on the burial tolerance of the blue mussel, Mytilus edulis: considerations for the management of marine aggregate dredging, PLoS One, 11, e0147534, https://doi.org/10.1371/journal.pone.0147534, 2016.

Deloffre, J., Verney, R., Lafite, R., Lesueur, P., Lesourd, S., and Cundy, A. B.: Sedimentation on intertidal mudflats in the lower part of macrotidal estuaries: sedimentation rhythms and their preservation, Mar. Geol., 241, 19-32, 2007.

De Vriend, H. J., Wang, Z., Ysebaert, T., Herman, P. M. J., and Ding, P.: Eco-morphological problems in the Yangtze estuary and the Western Scheldt, Wetlands, 31, 1033-1042, 2011.

Ellis, J., Cummings, V., Hewitt, J., Thrush, S., and Norkko, A.: Determining effects of suspended sediment on condition of a suspension feeding bivalve (Atrina zelandica): results of a survey, a laboratory experiment and a field transplant experiment, J. Exp. Mar. Bio. Ecol., 267, 147-174, 2002.

Essink, K.: Ecological effects of dumping of dredged sediments; options for managements, J. Coast. Conserv., 5, 69-80, 1999.

François, F., Gerino, M., Stora, G., Durbec, J., and Poggiale, J.: Functional approach to sediment reworking by gallery-forming macrobenthic organisms: modeling and application with the polychaete Nereis diversicolor, Mar. Ecol.-Prog. Ser., 229, 127 136, 2002.

Glud, R. N.: Oxygen dynamics of marine sediments, Mar. Biol. Res., 4, 243-289, 2008.

Hedman, J. E., Gunnarsson, J. S., Samuelsson, G., and Gilbert, F.: Particle reworking and solute transport by the sediment-living polychaetes Marenzelleria neglecta and Hediste diversicolor, J. Exp. Mar. Bio. Ecol., 407, 294-301, 2011.

Herman, P. M. J., Middelburg, J. J., van de Koppel, J., and Heip, C. H. R.: Ecology of estuarine macrobenthos, Adv. Ecol. Res., 29, 195-240, 1999.

Hohaia, A., Vopel, K., and Pilditch, C. A.: Thin terrestrial sediment deposits on intertidal sandflats: effects on pore-water so- 
lutes and juvenile bivalve burial behaviour, Biogeosciences, 11, 2225-2235, https://doi.org/10.5194/bg-11-2225-2014, 2014.

Hooper, D. U., Chapin, F. S., Ewel, J. J., Hector, A., Inchausti, P., Lavorel, S., and Lawton, J. H.: Effects of biodiversity on ecosystem functioning: a consensus of current knowledge, Ecol. Monogr., 75, 3-35, 2005.

Hu, Z., Lenting, W., Van Der Wal, D., and Bouma, T. J.: Continuous monitoring bed-level dynamics on an intertidal flat: introducing novel, stand-alone high-resolution sed-sensors, Geomorphology, 245, 223-230, 2015.

Jeuken, M. C. J. L. and Wang, Z. B.: Impact of dredging and dumping on the stability of ebb-flood channel systems, Coast. Eng., 57, 553-566, 2010.

Kristensen, E., Penha-Lopes, G., Delefosse, M., Valdemarsen, T., Quintana, C. O., and Banta, G. T.: What is bioturbation? The need for a precise definition for fauna in aquatic sciences, Mar. Ecol.-Prog. Ser., 446, 285-302, 2012.

Kristensen, K. and Hansen, K.: Transport of carbon dioxide and ammonium in bioturbated (Nereis diversicolor) coastal, marine sediments, Biogeochemistry, 45, 147-168, 1999.

Larson, F. and Sundbäck, K.: Recovery of microphytobenthos and benthic functions after sediment deposition, Mar. Ecol.-Prog. Ser., 446, 31-44, 2012.

Lohrer, A. M., Thrush, S. F., Hewitt, J. E., Berkenbusch, K., Ahrens, M., and Cummings, V. J.: Terrestrially derived sediment: response of marine macrobenthic communities to thin terrigenous deposits, Mar. Ecol.-Prog. Ser., 273, 121-138, 2004.

Mahaut, M. L., Sibuet, M., and Shirayama, Y.: Weight-dependent respiration rates in deep-sea organisms, Deep-Sea Res. Pt. I, 42, 1575-1582, 1995.

Marion, C., Anthony, E. J., and Trentesaux, A.: Short-term (=2 yrs) estuarine mudflat and saltmarsh sedimentation: high-resolution data from ultrasonic altimetery, rod surface-elevation table, and filter traps, Estuar. Coast. Shelf Sc., 83, 475-484, 2009.

MathWorks Inc.: Matlab v8.1, Natick, Massachusetts, USA, 2013.

Meire, P., Ysebaert, T., Van Damme, S., Van Den Bergh, E., Maris, T., and Struyf, E.: The Scheldt estuary: a description of a changing ecosystem, Hydrobiologia, 540, 1-11, 2005.

Montserrat, F., Suykerbuyk, W., Al-Busaidi, R., Bouma, T. J., van der Wal, D., and Herman, P. M. J.: Effects of mud sedimentation on lugworm ecosystem engineering, J. Sea Res., 65, 170-181, 2011.

Parsons, T. R., Maita, Y., and Lalli, C. M.: A Manual of Chemical and Biological Methods for Seawater Analysis, 1st Edn., New York, Pergamon Press, 1984.

Queirós, A. M., Birchenough, S. N. R., Bremner, J., Godbold, J. A., Parker, R. E., Romero-Ramirez, A., Reiss, H., Solan, M., Somerfield, P. J., Van Colen, C., Van Hoey, G., and Widdicombe, S.: A bioturbation classification of European marine infaunal invertebrates, Ecol. Evol., 3, 3958-3985, 2013.

R Development Core Team: R: A language and environment for statistical computing, Vienna, Austria, 2013.

Renz, J. R. and Forster, S.: Effects of bio-irrigation by the three sibling species of Marenzelleria spp. on solute fluxes and porewater nutrient profiles, Mar. Ecol.-Prog. Ser., 505, 145-159, 2014.

Riedel, B., Zuschin, M., Haselmair, A., and Stachowitsch, M.: Oxygen depletion under glass: behavioural responses of benthic macrofauna to induced anoxia in the northern Adriatic, J. Exp. Mar. Bio. Ecol., 367, 17-27, 2008.
Riisgaard, H. U. and Larsen, P. S.: Water pumping and analysis of flow in burrowing zoobenthos: an overview, Aquat. Ecol., 39, 237-258, 2005.

Rodil, I. F., Lohrer, A. M., Chiaroni, L. D., Hewitt, J. E., and Thrush, S. F.: Disturbance of sandflats by thin terrigenous sediment deposits: consequences for primary production and nutrient cycling, Ecol. Appl., 21, 416-426, 2011.

Shi, B. W., Yang, S. L., Wang, Y. P., Bouma, T. J., and Zhu, Q.: Relating accretion and erosion at an exposed tidal wetland to the bottom shear stress of combined current-wave action, Geomorphology, 138, 380-389, 2012.

Sistermans, W. C. H., Hummel, H., Dekker, A., and Dek, L. A.: Inventarisatie Macrofauna Westerschelde Najaar 2005: Rapportage in Het Kader van de Evaluatie van de Verdieping van de Westerschelde, NIOO-CEME, Yerseke, 2006.

Solan, M., Cardinale, B. J., Downing, A. L., Engelhardt, K. A. M., Ruesink, J. L., and Srivastava, D. S.: Extinction and ecosystem function in the marine benthos, Science, 306, 1177-1180, 2004.

Thrush, S. F., Hewitt, J. E., Norkko, A., Cummings, V. J., and Funnell, G. A.: Macrobenthic recovery processes following catastrophic sedimentation on estuarine sandflats, Ecol. Appl., 13, 1433-1455, 2003.

Thrush, S. F., Hewitt, J. E., Cummings, V. J., Ellis, J. I., Hatton, C., Lohrer, A., and Norkko, A.: Muddy waters: elevating sediment input to coastal and estuarine habitats, Front. Ecol. Environ., 2, 299-306, 2004.

Thrush, S. F., Hewitt, J. E., Gibbs, M., Lundquist, C., and Norkko, A.: Functional role of large organisms in intertidal communities: community effects and ecosystem function, Ecosystems, 9, 1029-1040, 2006.

Townsend, M., Thrush, S. F., Hewitt, J. E., Lohrer, A. M., and McCartain, L.: Behavioural changes in the tellinid bivalve $\mathrm{Ma}$ comona liliana (Iredale, 1915) following exposure to a thin terrigenous sediment deposition event: evidence from time-lapse photography, Cah. Biol. Mar., 55, 475-483, 2014.

Van Colen, C., Montserrat, F., Vincx, M., Herman, P. M. J., Ysebaert, T., and Degraer, S. Macrobenthic recovery from hypoxia in an estuarine tidal mudflat, Mar. Ecol.-Prog. Ser., 372, 31-42, 2008.

Van Colen, C., De Backer, A., Meulepas, G., van der Wal, D., Vincx, M., Degraer, S., and Ysebaert, T.: Diversity, trait displacement and shifts in assemblage structure of tidal flat deposit feeders along a gradient of hydrodynamic stress, Mar. Ecol.-Prog. Ser., 406, 79-89, 2010.

Van Colen, C., Rossi, F., Montserrat, F., Andersson, M. G. I., Gribsholt, B., Herman, P. M. J., Degraer, S., Vincx, M., Ysebaert, T., and Middelburg, J. J.: Organism-sediment interactions govern post-hypoxia recovery of ecosystem functioning, PLoS One, 7, e49795, https://doi.org/10.1371/journal.pone.0049795, 2012.

Van Colen, C., Thrush, S. F., Vincx, M., and Ysebaert, T.: Conditional responses of benthic communities to interference from an intertidal bivalve, PLoS One, 8, e65861, https://doi.org/10.1371/journal.pone.0065861, 2013.

van der Wal, D., Forster, R. M., Rossi, F., Hummel, H., Ysebaert, T., Roose, F., and Herman, P. M. J.: Ecological evaluation of an experimental beneficial use scheme for dredged sediment disposal in shallow tidal waters, Mar. Pollut. Bull., 62, 99-108, 2011.

Van Lancker, V. and Baeye, M.: Wave glider monitoring of sediment transport and dredge plumes in a shallow 
marine sandbank environment, PLoS One, 10, e0128948, https://doi.org/10.1371/journal.pone.0128948, 2015.

Villnäs, A., Norkko, J., Lukkari, K., Hewitt, J., and Norkko, A.: Consequences of increasing hypoxic disturbance on benthic communities and ecosystem functioning, PLoS One, 7, e44920, https://doi.org/10.1371/journal.pone.0044920 , 2012.

Weerman, E. J., Herman, P. M. J., and Van De Koppel, J.: Top-down control inhibits spatial self-organization of a patterned landscape, Ecology, 92, 487-495, 2011.

Wheatcroft, R. A., Jumars, P. A., Smith, C. R., and Nowell, A. R. M.: A mechanistic view of the particulate biodiffusion coefficient: step lengths, rest periods and transport directions, J. Mar. Res., 48, 177-207, 1990.

Widdows, J., Blauw, A., Heip, C. H. R., Herman, P. M. J., Lucas, C. H., Middelburg, J. J., Schmidt, S., Brinsley, M. D., Twisk, F., and Verbeek, H.: Role of physical and biological processes in sediment dynamics of a tidal flat in Westerschelde estuary, SW Netherlands, Mar. Ecol.-Prog. Ser., 274, 41-56, 2004.
Wijsman, J. W. M., Herman, P. M. J., and Gomoiu, M. T.: Spatial distribution in sediment characteristics and benthic activity on the northwestern Black Sea shelf, Mar. Ecol.-Prog. Ser., 181, 25 39, 1999.

Wong, M. C. and Dowd, M.: Patterns in taxonomic and functional diversity of macrobenthic invertebrates across seagrass habitats: a case study in Atlantic Canada, Estuar. Coast., 38, 2323-2336, 2015.

Wrede, A., Dannheim, J., Gutow, L., and Brey, T.: Who really matters?: influence of German Bight key bioturbators on biogeochemical cycling and sediment turnover biogeochemical cycling and sediment turnover, J. Exp. Mar. Bio. Ecol., 488, 92-101, 2017.

Zheng, B.: Sustainabililty of the multi-channel system in the Westerschelde under influence of dredging and disposal, in: Eproceedings of the 36th IAHR World Congress, 65-70, IAHR, the Hague, the Netherlands, 2015. 